\title{
ОСОБЛИВОСТІ РЕФОРМУВАННЯ ЗМІСТУ ОСВІТИ МАЙБУТНІХ ЛІКАРІВ-СТОМАТОЛОГІВ (початок XXI століття)
}

personal level of formation of its competencies]. Physical-mathematical education: a scientific journal. Sumy, vol. 3(13), pp. 160-165. [in Ukrainian].

3. Morze, N. V. \& Kocharyan, A. B. (2014). Model standartu IKT-kompetentnosti vykladachiv universytetu $v$ konteksti pidvyshchennia yakosti osvity [Model of the standard of ICT competency of university teachers in the context of improving the quality of education]. The information technologies and teaching aids. Vol. 43, issue 5, pp. 27-39. [in Ukrainian].
4. Struktura IKT-kompetentnosti uchiteley. Rekomendatsii YuNYeSKO [Structure of ICT competency of teachers. UNESCO Recommendations]. [Electronic resource]. Retrieved from: http://iteach.com.ua/files//content/ 5EDCFd01.pdf [in Russian].

5. Permyakov, O. E. (2009). Razvitie sistem otsenki kachestva podgotovki spetsialistov [Development of systems for assessing the quality of training specialists]. Extended abstract of Doctor's thesis. St. Petersburg.[in Russian].

Стаття надійшла до редакції 16.01.2018

Світлана Цюра, кандидат педагогічних наук, доиент кафедри загальної та сочіальної педагогіки Львівського національного університету імені Івана Франка

Наталія Солина, асистент кафедри стоматологї̈ дитячого віку Львівського національного медичного університету імені Данила Галищького

\section{ОСОБЛИВОСТІ РЕФОРМУВАННЯ ЗМІСТУ ОСВІТИ МАЙБУТНІХ ЛІКАРІВ- СТОМАТОЛОГІВ (початок ХХІ століття)}

У статті визначено, щуо ознаки вищої стоматологічної освіти в Украӥні обумовлені: змінами в сфері стоматологічної допомоги, зростанням вимог до ї̈ стандартів, теоретично складним змістом освіти. 3 а етапами реформування змісту освіти у 2003, 2007, 2009, 2015 - 2016 роках узагальнено його характерні особливості: збереження і розвиток єдиних стандартів професійної підготовки фахівия у вищих медичних закладах України з переходом у 2016 р. на наскрізну 5-річну програму підготовки магістрів стоматологї.

Ключові слова: професійна підготовка лікаря-стоматолога, зміст освіти лікаря-стоматолога, професійна підготовка фахівия, стоматологічна освіта.

Табл. 4. Літ. 6.

Svitlana Tsyura, Ph.D.(Pedagogy), Associate Professor of the General and Social Pedagogy Department Lviv Ivan Franko National University

Nataliya Solyna, Assistant of the Pediatric Dentistry Department Danylo Halytskiy Lviv National Medical University

\section{THE FEATURES OF REFORMING THE ESSENCE OF EDUCATION OF FUTURE DENTISTS (the beginning of the XXI century)}

The article generalizes that the characteristic features of higher dental education in Ukraine are due to constant changes in the field of dental care, its technological component, materials and tools, procedures, techniques of treatment; increasing requirements for standards and technologies of treatment, which the potential consumer sets in front of the system of dental services; theoretically complex content of fundamental disciplines, which is the basis of dental education and the requirement for its quality. The reform of the essence of higher medical education in Ukraine is also conditioned by the general reforms of the educational sector, the European integration tendencies, the transition to the two-level system of training of specialists with higher education and a credit-module system of organizing the training and assessment of students.' knowledge.The main changes that have taken place were analyzed during the reform stages in 2003, 2007, 2009 and 2015 - 2016. The characteristic features of reforming the essence of education of future dentists are summarized: the preservation and development of uniform standards of professional training of specialists in higher medical institutions of Ukraine with the transition in 2016 to the cross-cutting 5-year training program ("Master of Dentistry", qualification "Dentist"); reorganization of the content of education in accordance with European standards of its layout and orientation, the list and names of disciplines have been brought into line with their names in the curriculum of medical faculties and medical universities of Europe; general reduction of the student's academic load; improvement of the components of curriculum, of the content and credit structure, which initiates the possibility of academic mobility of students regardless of the semester of study.

Keywords: professional training of a dentist, the essence of education of a dentist, the professional training of a specialist, dental education. 


\section{ОСОБЛИВОСТІ РЕФОРМУВАННЯ ЗМІСТУ ОСВІТИ МАЙБУТНІХ ЛІКАРІВ-СТОМАТОЛОГІВ (початок XXI століття)}

$\Pi$ остановка проблеми. Кінець XX початок XXI століття - це період, коли у контексті загальних глобалізаційних процесів, євроінтеграційних чинників та тенденцій, нових вимог ринку праці та сфери медичних послуг відбувся суттєвий перегляд основних стандартів та реформування на цій основі змісту медичної освіти майбутнього лікарястоматолога та особливостей його організації.

Реформування змісту стоматологічної освіти у сучасних університетах, які працюють на рівні транснаціональному відбувається 3 урахуванням вимог, що їх ставить до майбутнього фахівця міжнародний ринок праці. Дотримання сучасних протоколів лікування, високих стандартів фахової діяльності медичних (стоматологічних) працівників підлягає контролю не лише з боку споживачів послуг, але й професійних лікарських об'єднань, державних служб та представників.

Наукові дослідження у галузі медицини та фармації, лікарська практика, наукові конференції, професійні виставки стають джерелом постійної зміни фахово важливих знань, умінь, технологій і методів, що апробуються, насамперед, у країнах де технологічне оснащення клінік є значно вищим ніж у середньому в Україні. Відповідно у змісті медичної (стоматологічної) освіти на рівні дипломному і післядипломному перманентно відбуваються зміни навчальних планів та програм.

Аналіз останніх досліджень і публікацій. Теоретичні та практичні аспекти організаційнопедагогічної діяльності вищих медичних навчальних закладів України, підготовку майбутніх медиків, запровадження кредитномодульної технології у навчальних закладах аналізували М. Гжегоцький, О. Волосовець, В. Вороненко, Б. Зіменковський, Ю. П'ятницький. Питання реорганізації освітніх стандартів і особливості організації медичної освіти в Україні та за кордоном, розглянуто Я. Цехмістером, Б. Криштопою, Л. Ковальчуком. Спрямованість і завдання реформування системи оцінювання якості знань студентів вищих медичних навчальних закладів аналізували I. Булах, О. Волосовець. Організаційно-педагогічні умови здобуття стоматологічної освіти іноземними студентами вивчав В. Гуменюк; характерні тенденції організації та управління навчальним процесом у вищих медичних навчальних закладах, реформування змісту стоматологічної освіти - О. Гуменюк.

Метою статті $\epsilon$ характеристика основних особливостей та спрямованості реформування змісту освіти майбутніх лікарів-стоматологів (початок XXI століття).
Виклад основних результатів дослідження. Шляхом аналізу теоретичних джерел виявлено, що характерні ознаки сучасної вищої стоматологічної освіти обумовлені загальними змінами й процесами в сфері медичної (стоматологічної) допомоги, серед них такі:

- значний обсяг та теоретична складність фундаментальних дисциплін, що є основою стоматологічної освіти й загальних медичних знань;

- високий рівень та великий обсяг технологічної складової професійної освіти майбутнього лікарястоматолога;

- темпи розвитку сфери стоматологічного обслуговування населення, матеріалів та засобів, що використовуються в професійній діяльності, зміни в процедурах, техніках лікування, матеріально-технічному забезпеченні;

- зростання вимог до стандартів, процедур та технологій лікування, які ставить перед системою стоматологічних послуг їх потенційний споживач;

- глобальний характер зростання вимог суспільства до фахової діяльності, особливо в сфері охорони здоров'я, що привело до виникнення, узгодження, врахування медичними службами різних країн стандартів, кваліфікацій та протоколів надання медичної допомоги.

Реформування змісту вищої методичної освіти в Україні зумовлене також загальними реформами освітньої галузі, прийняттям Законів України “Про освіту" (2014), "Про вищу освіту", євроінтеграційними тенденціями в освітній галузі, переходом на двоступеневу систему підготовки фахівців з вищою освітою та кредитно-модульної системи організації навчання й оцінювання знань студентів.

До найбільш характерних особливостей реформування змісту освіти майбутніх лікарів стоматологів відносимо такі:

- наявність єдиних стандартів професійної підготовки фахівця у вищих медичних закладах України. Навчальні плани спеціальності “стоматологія” і Типові навчальні програми дисциплін як основної, так і вибіркової компоненти розробляються робочими групами та затверджуються Міністерством охорони здоров'я;

- реорганізація змісту освіти відповідно до європейських стандартів його компонування та спрямованості;

- загальне скорочення навчального навантаження студента, насамперед, аудиторного та збільшення ваги самостійної роботи студента;

- перехід до підготовки фахівців відповідно до освітнього рівня “магістр";

- удосконалення складових навчальних планів 


\section{ОСОБЛИВОСТІ РЕФОРМУВАННЯ ЗМІСТУ ОСВІТИ МАЙБУТНІХ ЛІКАРІВ-СТОМАТОЛОГІВ (початок XXI століття)}

у їх іменній та кредитній структурі, що започатковує можливість академічної мобільності студентів незалежно від семестру навчання.

Конкретизуючи основні зміни, що відбулися протягом неповних двох десятиліть XXI століття відмітимо їх за етапами реформування.

Станом на початок 2000-х років підготовка майбутніх стоматологів, кваліфікація “лікарстоматолог”, здійснювалася відповідно до Навчального плану підготовки фахівців освітньокваліфікаційного рівня “спеціаліст” у вищих медичних навчальних закладах України III - IV рівня акредитації, відповідно до Наказу MO3 “Про затвердження Положення про особливості ступеневої освіти медичного спрямування" (2000 p.) [2].

Наказом МО3 України (2003, №352) затверджено Навчальний план підготовки фахівців з вищою освітою освітньо-кваліфікаційного рівня “спеціаліст" за спеціальністю 7.110106 “Стоматологія" з наступним обсягом навчальних годин (Таблиця 1). надзвичайних ситуацій”. Зазнали змін блоки гуманітарної та соціально-економічної підготовки, природничо-наукової підготовки, курси за вибором. Обсяг навчальних годин розподілився наступним чином (Таблиия 2).

Наказом МО3 України (2009 р., №929) було затверджено Навчальний план, у якому перелік і назви дисциплін привели у відповідність до їх назв у навчальних планах медичних факультетів та медичних університетів Свропи, що зумовило скорочення кількості навчальних дисциплін у кожному блоці та зменшення кількості навчальних годин, крім блоку “природничо-наукова підготовка" (Таблиия 3).

Затверджений у 2010 році (наказ №541) Навчальний план був новою редакцією попереднього, жодних змін щодо кількості навчальних годин та їх розподілу за блоками дисциплін не було зроблено. Суттєві зміни Навчального плану підготовки фахівців освітньокваліфікаційного рівня “спеціаліст” у вищих навчальних закладах MO3 України за

Таблиця 1.

Розподіл годин навчального навантаження у типових навчальних планах зі спеціальності “Стоматологія" [5]

\begin{tabular}{|c|c|c|c|c|}
\hline Блок дисциплін & $\begin{array}{c}\text { Всього } \\
\text { (год.) }\end{array}$ & $\begin{array}{l}\text { Аудиторних } \\
\text { (год.) }\end{array}$ & $\begin{array}{l}\text { СРС } \\
\text { (год.) }\end{array}$ & Кредити \\
\hline $\begin{array}{l}\text { 1. Гуманітарна та соціально-економічна } \\
\text { підготовка }\end{array}$ & 1485 & 798 & 687 & 27,5 \\
\hline 2. Природничо-наукова підготовка & 1647 & 1048 & 599 & 30,5 \\
\hline \multicolumn{5}{|l|}{ 3. Професійна підготовка: } \\
\hline $\begin{array}{l}3.1 \text { Професійно-орієнтовані } \\
\text { фундаментальні дисципліни }\end{array}$ & 540 & 324 & 216 & 10 \\
\hline 3.2 Медико-профілактичні дисципліни & 162 & 108 & 54 & 3 \\
\hline 3.3Професійно-орієнтовані дисципліни & 5346 & 3224 & 2122 & 99 \\
\hline 3.4 Військова (медична) підготовка & 351 & 218 & 133 & 6,5 \\
\hline 4. Курси за вибором & 459 & 180 & 279 & 8,5 \\
\hline Всього за 5 років підготовки & 9990 & 5900 & 4090 & 185 \\
\hline Практика & 1026 & 684 & 342 & 19 \\
\hline Всього за планом & 11016 & 6584 & 4432 & 204 \\
\hline
\end{tabular}

У 2007 році з переліку нормативних було вилучено дисципліну "Військова (медична) підготовка” і перенесено їі до переліку вибіркових дисциплін навчальних закладів, де $є$ військові кафедри. У зміст було введено дисципліни "Клінічна імунологія" та "Медицина спеціальністю 7.12010005 “Стоматологія” відбулися у 2015 році. Кількість навчальних годин між блоками дисциплін розподілили таким чином, що було збільшено кількість навчального часу для блоків професійної підготовки та курсів за вибором, а також збільшено кількість навчальних 
Таблиця 2.

Розподіл годин навчального навантаження у типов их навчальних планах зі спеціальності “Стоматологія" [3]

\begin{tabular}{|c|c|c|c|c|}
\hline Блок дисциплін & $\begin{array}{c}\text { Всього } \\
\text { (год.) }\end{array}$ & $\begin{array}{l}\text { Аудиторних } \\
\text { (год.) }\end{array}$ & $\begin{array}{l}\text { СРC } \\
\text { (год.) }\end{array}$ & Кредити \\
\hline $\begin{array}{l}\text { 1. Гуманітарна та соціально-економічна } \\
\text { підготовка }\end{array}$ & 1566 & 852 & 714 & 29 \\
\hline 2. Природничо-наукова підготовка & 1674 & 1060 & 614 & 31 \\
\hline \multicolumn{5}{|l|}{ 3. Професійна підготовка: } \\
\hline $\begin{array}{l}3.1 \text { Професійно-орієнтовані } \\
\text { фундаментальні дисципліни }\end{array}$ & 540 & 324 & 216 & 10 \\
\hline 3.2 Медико-профілактичні дисципліни & 162 & 108 & 54 & 3 \\
\hline 3.3Професійно-орієнтовані дисципліни & 5616 & 3358 & 2222 & 104 \\
\hline 4. Курси за вибором & 432 & 171 & 261 & 8 \\
\hline Всього за 5 років підготовки & 9990 & 5909 & 4081 & 185 \\
\hline Практика & 1026 & & & 19 \\
\hline Всього за планом & 11016 & 5909 & 4081 & 204 \\
\hline
\end{tabular}

Розподіл годин навчального навантаження у типових навчальних планах зі спеціальності “Стоматологія" [4]

\begin{tabular}{|l|c|c|c|c|}
\hline Блок дисциплін & $\begin{array}{c}\text { Всього } \\
\text { (год.) }\end{array}$ & $\begin{array}{c}\text { Аудит. } \\
\text { (год.) }\end{array}$ & $\begin{array}{c}\text { СРС } \\
\text { (год.) }\end{array}$ & Кредити \\
\hline \begin{tabular}{l|l|l|l|} 
1. Гуманітарна та соціально-економічна \\
підготовка
\end{tabular} & 705 & 350 & 355 & 23,5 \\
\hline 2. Природничо-наукова підготовка & 1980 & 1200 & 780 & 66 \\
\hline 3. Професійна підготовка & 6075 & 4076 & 1999 & 202,5 \\
\hline 4. Курси за вибором & 240 & 120 & 120 & 8 \\
\hline Всього за 5 років підготовки & $\mathbf{9 0 0 0}$ & $\mathbf{5 7 4 6}$ & $\mathbf{3 2 5 4}$ & $\mathbf{3 0 0}$ \\
\hline Практика & 930 & & & 31 \\
\hline
\end{tabular}

годин, передбачених для самостійної роботи студентів (Таблиия 4).

Таким чином відбулося суттєве скорочення навчального навантаження студентів 32003 по 2016 рік на 1666 годин більше ніж на 15\%, 3 них найбільше скорочено кількість годин на вивчення циклу дисциплін гуманітарної та соціальноекономічної підготовки - 32\%. Зберігається обмеження на дисципліни вільного вибору студента - 3,86\%, 12 кредитів від загальної кількості 300 на весь період навчання.

Вагомі зміни, які можна віднести до структурних було узгоджено на XIII Всеукраїнській науково-практичній конференції 3 міжнародною участю “Актуальні питання якості медичної освіти” (12 - 13 травня 2016 року, м. Тернопіль). На конференції ухвалено Проект стандарту вищої освіти другого (магістерського) рівня підготовки здобувачів вищої освіти освітнього ступеня "Магістр" галузі знань 22 “Охорона здоров’я” за спеціальністю 221 “Стоматологія”, на основі якого розроблено Примірний навчальний план підготовки фахівців другого (магістерського) рівня вказаної спеціальності кваліфікації освітньої "Магістр стоматології”, кваліфікації професійної “Лікарстоматолог”. Відповідно до нього підготовка магістра стоматології $є$ наскрізною програмою, яка триває 5 років і включає 300 кредитів. Всього передбачено 9350 академічних годин, з яких 4990 годин відведено на аудиторні заняття та 4360 на самостійну роботу [6]. Додатково до попередніх змін у зміст підготовки у блоці дисциплін "Професійна підготовка" додано 29 кредитів дисципліни "Підготовка офіцерів запасу”, з яких 3 кредити СКТС (90 год, в т.ч. 50 аудиторних) обов'язкові для вивчення усіма здобувачами вищої медичної освіти в Україні. 
Таблиця 4.

Розподіл годин навчального навантаження у типових навчальних планах зі спеціальності “Стоматологія" [1]

\begin{tabular}{|l|c|c|c|c|}
\hline Блок дисциплін & $\begin{array}{c}\text { Всього } \\
\text { (год.) }\end{array}$ & $\begin{array}{c}\text { Аудиторних } \\
\text { (год.) }\end{array}$ & $\begin{array}{c}\text { СРС } \\
\text { (год.) }\end{array}$ & Кредити \\
\hline \begin{tabular}{|l|c|c|c|} 
1. Гуманітарна та соціально-економічна \\
підготовка
\end{tabular} & 510 & 170 & 340 & 17 \\
\hline 2. Природничо-наукова підготовка & 1890 & 1090 & 800 & 63 \\
\hline 3. Професійна підготовка & 6240 & 3580 & 2660 & 208 \\
\hline 4. Курси за вибором & 360 & 100 & 260 & 12 \\
\hline Фіз. виховання & 320 & 60 & 260 & \\
\hline Всього за 5 років підготовки & $\mathbf{9 3 2 0}$ & $\mathbf{5 0 0 0}$ & $\mathbf{4 3 2 0}$ & $\mathbf{3 0 0}$ \\
\hline
\end{tabular}

Висновки. Аналіз особливостей та спрямованості реформування змісту освіти майбутніх лікарів-стоматологів в Україні дав змогу узагальнити такі основні зміни як: збереження i розвиток єдиних стандартів професійної підготовки фахівця у вищих медичних закладах України 3 переходом на наскрізну 5-річну програму підготовки (“Магістр стоматології”, кваліфікація “Лікар-стоматолог”); реорганізація змісту освіти відповідно до європейських стандартів його компонування та спрямованості, назви дисциплін привели у відповідність до їх назв у навчальних планах медичних факультетів та медичних університетів Європи; загальне скорочення навчального навантаження студента; удосконалення складових навчальних планів, у їх змістовій та кредитній структурі, що започатковує можливість академічної мобільності студентів незалежно від семестру навчання.

\section{ЛIТЕРАТУРА}

1. Навчальний план підготовки фахівців освітньокваліфікаційного рівня спеціаліст кваліфікації лікарстоматолог у ВНЗ МОЗ Украӥни за спеціальністю 7.12010005 “Стоматологія”. - Київ, 2015. - 12 c.

2. Наказ Міністерства охорони здоров'я “Про затвердження Положення про особливості ступеневої освіти медичного спрямування” № 35 від 24.02 .2000 p. [Електронний ресурс]. - Режим docmyny: http://zakon3.rada.gov.ua/laws/show/ z0370-00

3. Наказ МОЗ України "Про внесення змін до наказу Міністерства охорони здоров'я України від 25.07 .2003 p. № 352 “Про затвердження та введення нового навчального плану підготовки фахівиів за спеціальністю “Стоматологія” № 415 від 23.07.2007 p. [Електронний ресурс]. - Режим docmyny: http://moz.gov.ua/ua/print/dn 20070723 415. html.

4. Наказ МОЗ України "Про внесення змін до Навчального плану підготовки фахівців освітньокваліфікачійного рівня "Спеціаліст" кваліфікачіі
“Лікар-стоматолог” у вищих навчальних закладах IV рівня акредитації за спеціальністю “Стоматологія", затвердженого наказом МОЗ від 07.12 .2009 p. № 929” № 541 від 08.07.2010 p. [Електронний ресурс]. - Режим доступу: http:// www.moz.gov.ua/ua/portal/dn_20100708_541.html.

5. Наказ МОЗ України "Про затвердження та введення нового навчального плану підготовки фахівиів за спеиіальністю “Стоматологія” № 352 від 25.07.2003 p. [Електронний ресурс]. - Режим docmyny: http://uazakon.com/documents/date_b2/ pg_gxcroa/index.htm.

6. Примірний навчальний план підготовки фахівиів другого (магістерського) рівня вищої освіти галузі знань 22 “Охорона здоров'я” у вищих навчальних закладах МОЗ України за спеціальністю 222 “Медицина”, кваліфікації освітньої “магістр стоматології”, кваліфікаиї̈ професійної “Лікарстоматолог", від 26.07. 2016 p.

\section{REFERENCES}

1. Navchalnyi plan pidhotovky fakhivtsiv osvitnokvalifikatsiinoho rivnia spetsialist kvalifikatsii likarstomatoloh u VNZ MOZ Ukrainy za spetsialnistiu 7.12010005 "Stomatolohiia" (2015). [Curriculum of training specialists of educational qualification level "Specialist" qualification "Dentist" in the institution of higher education of the Ministry of Health of Ukraine in the specialty 7.12010005 "Dentistry"]. Kyiv, 12 p.[in Ukrainian]

2. Nakaz Ministerstva okhorony zdorovia "Pro zatverdzhennia Polozhennia pro osoblyvosti stupenevoi osvity medychnoho spriamuvannia" [Order of the Ministry of Health "On approval of the regulation on the peculiarities of graduate education in the medical sphere"]. No. 35 of 24.02.2000 [Electronic Resource]. Mode of access: http://zakon3.rada.gov.ua/laws/show/ z0370-00. [in Ukrainian].

3. Nakaz Ministerstva okhorony zdorovia "Pro zatverdzhennia Polozhennia pro osoblyvosti stupenevoi osvity medychnoho spriamuvannia" [Order of the Ministry of Health of Ukraine "On introduction changes to the order of the Ministry of Healthcare] of the Ukraine of 25.07.2003 No. 352"'On approval and 
introduction of a new curriculum for training specialists in the field of "Dentistry" 415 dated July 23, 2007 [Electronic resource]. Access mode: http: //moz.gov.ua/ ru/print/dn_20070723_415.html. [in Ukrainian].

4. Nakaz MOZ Ukrainy "Pro vnesennia zmin do Navchalnoho planu pidhotovky fakhivtsiv osvitnokvalifikatsiinoho rivnia "Spetsialist" kvalifikatsii "Likar-stomatoloh" u vyshchykh navchalnykh zakladakh IV rivnia akredytatsii za spetsialnistiu "Stomatolohiia" [Order of the Ministry of Health of Ukraine "On amendments to the Curriculum for the Training of Specialists in the Educational-Qualification Level "Specialist" in the qualification "Dentist"] in higher educational institutions of the IV level of accreditation in the specialty "Dentistry", approved by Order of the Ministry of Health of 07.12.2009, No. 929" No. 541 dated July 08, 2010 [Electronic resource]. Mode of access: http://www.moz.gov.ua/ua/portal/dn_20100708 541.html. [in Ukrainian].
5. Nakaz MOZ Ukrainy "Pro zatverdzhennia ta vvedennia novoho navchalnoho planu pidhotovky fakhivtsiv za spetsialnistiu "Stomatolohiia" [Order of the Ministry of Health of Ukraine "On approval and introduction of a new curriculum for training specialists in the field of "Dentistry"]. No. 352 dated 25.07.2003 [Electronic resource]. Access mode: http://uazakon.com/ documents/date b2/pg gxcroa/index.htm. [in Ukrainian].

6. Prymirnyi navchalnyi plan pidhotovky fakhivtsiv druhoho (mahisterskoho) rivnia vyshchoi osvity haluzi znan 22 "Okhorona zdorovia" [A detailed curriculum for the training of specialists in the second (master's) level of higher education in the field of knowledge 22 "Health care"] in higher education institutions of the Ministry of Health of Ukraine in the specialty 222 "Medicine", qualifications of educational "Master of dentistry", professional qualifications of "Dentist", from 26.07. 2016 [in Ukrainian].

Стаття надійшла до редакції 18.01.2018

УДК 378.091.33:811.111

Інна Лобачук, кандидат педагогічних наук, старший викладач кафедри методики навчання іноземних мов Вінницького державного педагогічного університету імені М. Коиююинського

\section{ЗАСТОСУВАННЯ СИТУАТИВНОГО МЕТОДУ НАВЧАННЯ У ВИКЛАДАННІ ІНОЗЕМНОЇ МОВИ}

У статті розкрито суть ситуативного методу навчання у викладанні іноземної мови, його ознаки та процеси. Обтрунтовано доиільність використання ситуативного методу у підготовиі студентів до іншомовного спілкування. Встановлено, щуо ситуативний метод передбачає формування необхідної комунікативної спроможності у сферах професійного спілкування в усній і писемній формі, яке реалізується через використання рольових ігор. Визначено роль і значення ефективного використання комунікативних рольових ігор при застосуванні ситуативного методу навчання у викладанні іноземної мови.

Ключові слова: ситуативний метод, ситуативне моделювання, комунікативний підхід, рольові ігри. Iim. 7.

Inna Lobachuk, Ph.D.(Pedagogy), Senior Lecturer of the Foreign Languages Teaching Methodology Department Vinnytsya Mukhaylo Kotsyubynskiy State Pedagogical University

\section{USINING SITUATIONAL METHOD IN FOREIGN LANGUAGES TEACHING}

The article describes the essence of the situational method in foreign languages teaching, its features and processes. The expediency of using situational method in preparing students for foreign language communication is substantiated.

It is established that the situational method involves the formation of the necessary communicative capacity in the spheres of professional communication in oral and written form, which is provided by the use of roleplaying games. The role and importance of effective use of communicative role-playing games in the application of situational learning method in foreign languages teaching is determined.

It is revealed that the use of a situational method in foreign languages teaching facilitates creative communication with students, acquisition of skills in cooperation in a team and the formation of responsibility for the tasks, the ability to build a balanced response, effective and rapid mastery of lexical and grammatical material.

It is proved that the use of alternative technologies in the process of foreign languages teaching, namely a situational approach, involves immersing students in a particular situation where they can find practical application of their knowledge, the proper use of vocabulary and grammatical rules; substantially increases the motivation and activity of the students; reinforce the motives of students to speak, read, listen and write in a foreign language; stimulates precisely to react in language situations, impeccably possessing the basic 